\title{
Poverty Alleviation: A Response to the Rural Woman's Diversification of Rural Activities in Bui Division, Cameroon
}

\author{
${ }^{1}$ Loveline Kongla Nsahlai*, ${ }^{2}$ Moye Eric Kongnso, ${ }^{3}$ Anastasia Kininla Kongnyuy, \& ${ }^{4}$ Jean-Yves \\ Ndjeussi Fotsa \\ ${ }^{1}$ Geography Department, Higher Teacher Training College, Bertoua - Cameroon \\ Email: nlove483@yahoo.com \\ ${ }^{2}$ Department of Geography and environmental planning, University of Dschang, Cameroon \\ Email: moyeeric@yahoo.com \\ ${ }^{3,4}$ Geography department, The University of Yaounde 1 , Cameroon \\ Email: ${ }^{3}$ anastasiakong26@yahoo.com; ${ }^{4}$ ndjeussifotsa@yahoo.fr
}

\begin{abstract}
Cameroon is one of the Sub-Saharan African countries that was greatly affected by poverty after the liberalization of the agricultural sector; poverty became deeply rooted amongst the 'rural masses' (especially women and children) in Bui Division. However, in a bid to combat the poverty situation, rural women embarked on the diversification of rural activities. That is, a shift from subsistence to market oriented agriculture and non-farm income generating activities. The main objective of this paper is to identify and assess the indicators of poverty alleviation as a result of the rural woman's diversification of rural activities in Bui Division. In order to attain this set objective, data was collected from secondary and primary sources. Using a random sampling technique for primary data collection, both qualitative and quantitative data was collected from rural women (35years and above) in 749 rural households by means of questionnaires; structured interviews; three focus group discussions; on-the-spot and participant observations. It was found that before the rural woman adopted the strategy of diversifying rural activities, $86 \%$ of children especially girl children were drop outs; $75 \%$ of housing infrastructure was poor; $80 \%$ of households were not able to have access to medical facilities; $91 \%$ families were undernourished and malnourished. Thanks to the diversification of rural activities, there is stimulation of economic growth via 'spending power of families (98\%); improved shelter (93\%); improved rights, equity/fairness of household members $(79 \%)$; breakdown of intergenerational poverty link (47\%); households' access to improved health/nutrition (99\%); and children's improved access to education (97\%). Having noticed that poverty has been alleviated in Bui Division thanks to the rural woman's diversification of rural activities, she should be considered as an indispensable actor in poverty alleviation: her diversified activities should be taken into consideration in poverty reduction strategy papers in a bid to easily combat poverty in rural milieus.
\end{abstract}

Keywords: Poverty alleviation, Rural woman, Diversification, Rural Activities, Gender, Bui Division.

\section{Introduction}

Poverty is a complex phenomenon, measured not only in terms of income and expenditure (spending power) but also in terms of individual social interactions and state of mental wellbeing. Poverty is a deprivation in terms of income, education, health, human and civil rights (Singleton, 2003). According to Awotide et al., (2010), poverty depicts poor nutrition, inadequate shelter and low health standards. Ade-Lawal et al., (1986) talk of food poverty in 
households which is based on the fact that food poverty is the most important of all the different dimensions of poverty facing the poor. Food is a basic essential for survival. Poverty in Africa is predominantly rural. More than $70 \%$ of the continent's poor people live in rural areas and depend on agriculture for food and livelihood; yet, development assistance to agriculture is decreasing (Handley et al., 2013). A purely objective explanation of poverty is mis-interpreted by a proliferation of socially defined issues and concerns both liberal and conservative perspectives. No theory of poverty has emerged that either subsumes or invalidates the others (Blank, 1997 cited by Bradshaw, 2005).

Poverty in its most general sense is the lack of basic necessities; food, shelter, medical care and safety. These necessities are based on shared values of human dignity. What is a necessity to one person is not necessarily a necessity to others. Needs may be relative to what is possible and are based on social definitions and past experiences. As opined by Bradshaw, (2005), 'the essence of poverty is inequality which implies a relative deprivation. People become poor not by a sudden event, although, it also happens that they become poor due to a combination of events as ascertained by Yan, (2010), who says that poverty is a gradual cumulative process of a sequence of events. The high rate of poverty is a major challenge that requires urgent measures to deal effectively with. Although various approaches have been tried to fight poverty, not much has been achieved as evidenced by the rising trends in poverty throughout the continent (Kehinde, 2010).

According to a World Bank Publication of 2012, cited by Lempert, (2020) there is no international treaty on poverty alleviation and no standard or list of its elements; there are several international laws, covenants and declarations that demonstrate an international consensus and commitment to the principles of poverty alleviation. However, no matter how diverse poverty is, the coping strategies cluster around some common themes. The most common is to supplement one's income through farming, casual labour, trading and engaging in other petty business activities (Akinde, 2010). Poverty alleviation entails having sufficient food, access to production assets, services, markets, income earning opportunities and the organizational / institutional means of achieving these; all of which imply sustainable improvement of income earning capacities. The main productive activities of rural women have a low value and a marginal position in the local and national economy as compared to those of men (BIT, 1996). Zergaw, (2007) opines that women especially female-headed households diversify their income sources as a survival strategy. Quite often, in African communities, the contributions of the rural woman in the diversification of activities for poverty alleviation are seldom valued. The rural woman's role in poverty alleviation via the diversification of rural activities tends to be unnoticed and is not recorded in statistics and mentioned in reports. This implies that her contributions are poorly understood and underestimated (Nsahlai, 2015).

There has been a slow growth in support for people living in poverty in Bui Division in particular and elsewhere in Cameroon, in response to the need to feed landless agricultural workers (rural women) who only have usufruct rights over land (Nsahlai, 2015). The rural woman in Bui Division cannot be held responsible for the severe manifestation of poverty in her setting; she could not strive on her own but depended on her husband's income gotten from cash crops. Her dependency was a cultural/historical norm that conditioned her existence. In her efforts to 'break through' poverty, she adopted a strategy of diversifying rural activities. Does the diversification of rural activities guarantees an improvement of the denigrated living standards of 
the rural masses in Bui Division? Whatever the case, this article strives to identify the indicators of poverty alleviation in the study area owing to the diversification of rural activities by the rural woman.

\section{Location of study area}

Bui Division is one of the administrative divisions of the North West Region of Cameroon. Bui Division lies approximately between latitudes $6^{\circ} 00^{\prime}$ and $6^{\circ} 31^{\prime}$ north of the equator and longitudes $9^{\circ} 45^{\prime}$ and $11^{\circ} 51^{\prime}$ east of the Greenwich meridian. Bui Division covers a surface area of about $2300^{2} \mathrm{~km}$ making for $13.3 \%$ of the land area of the North West Region. This Division is bounded to the north by Donga Mantung Division, to the south by Ngo-ketunjia Division, to the east by Noun Division (West Region) and to the west by Boyo Division (figure 1). Bui Division is divided into six sub-divisions which include: Kumbo $\left(520^{2} \mathrm{~km}\right)$, Jakiri $\left(478^{2}\right.$ $\mathrm{km})$, Oku $\left(244^{2} \mathrm{~km}\right)$, Noni $\left(314^{2} \mathrm{~km}\right)$, Mbven $\left(698^{2} \mathrm{~km}\right)$ and Nkum.

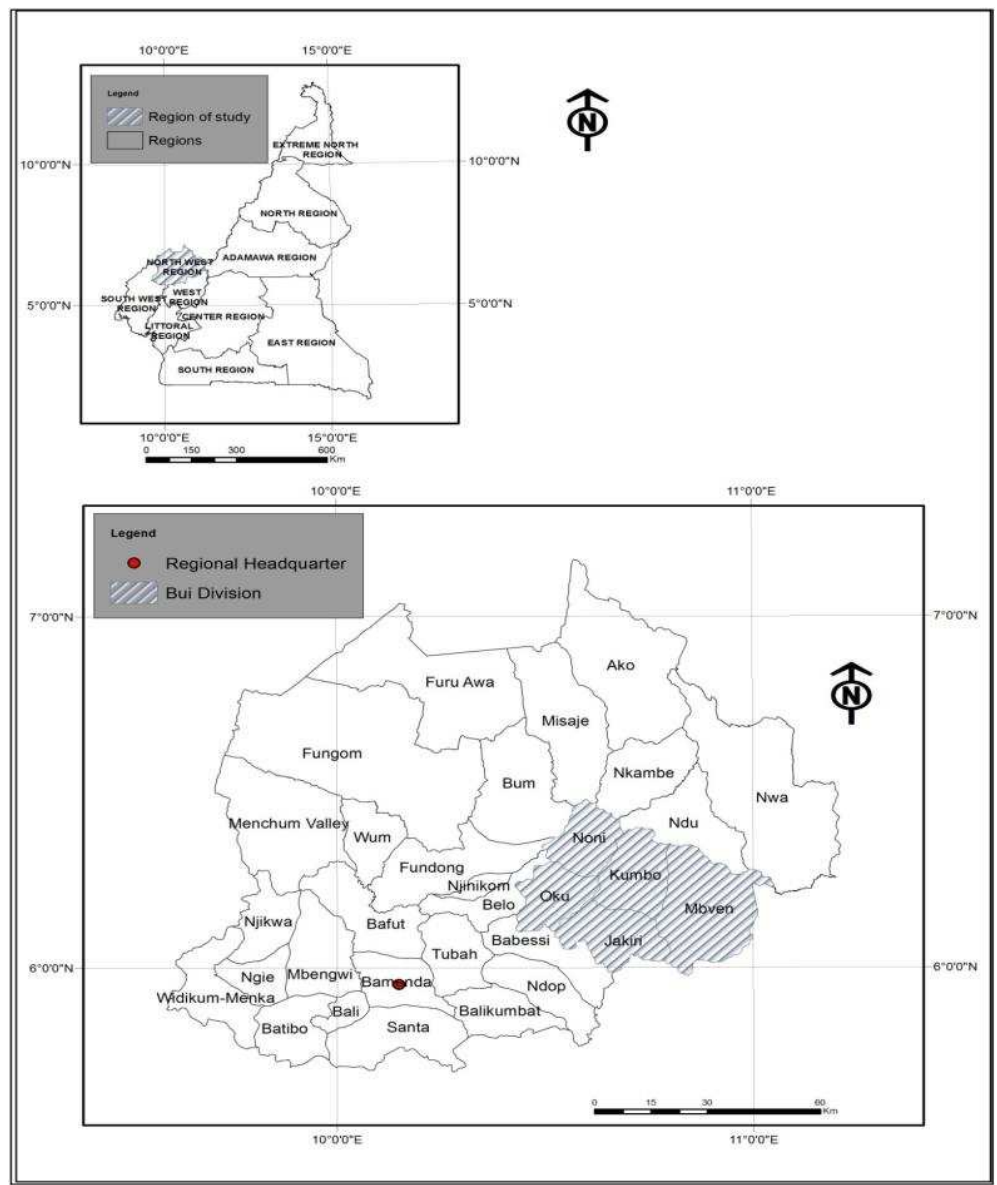

Figure 1: Bui Division in the North West Region of Cameroon

Source: Geospatial Informatics Services Consulting, Yaounde, 2014

\section{Methods and techniques of data collection}

The qualitative and quantitative research approaches have been used in this study. The first phase of data collection was done in libraries, internet and other documentation centres where publications, books, and articles related to the subject matter were consulted and analysed 
by way of content analysis, reference and abstract guides. The second phase was field research which was carried out in 2018 within 749 households randomly selected in villages within the six sub divisions of the study area. Required data was gotten by way of well-designed questionnaires made up of open ended and closed ended questions; participant observations (taking of photographs); personal interviews (made of close and open questions); and group interviews (three small groups of 8 to 10 rural women) were organised in three localities at different periods where rural women were simultaneously interviewed based on prepared wellstructured questions.

\section{Results and discussion}

\subsection{Manifestations of poverty in Bui Division}

Poverty in the study area is manifested differently within households; that is, economic, social, psychological, intellectual, cultural and/or political wise. With poverty situation which has either been relatively chronic and/or absolutely chronic, many households have been unable to send their children to school, pay their school fees and buy other school facilitating tools. As such, many parents could not send their children to school; $86 \%$ of children especially girl children could only complete their primary education, $69 \%$ of girl children dropped out of school without completing primary education. Most girl children (89\%) were obliged by their parents to get married at their early ages so as to reduce family burden. A household could consume the same meal everyday within a calendar year. Food that was consumed on daily bases by most families was corn fufu and huckleberry (at times with little or no oil). The other food crops such as groundnuts, beans and plantains cultivated by means of subsistence in small quantities were instead sold in order to get money to be used in grinding corn into corn flour, buying salt, palm oil and other small basic needs. As such, $91 \%$ families were undernourished and malnourished. It is revealed in the field that $80 \%$ of households were not able to have access to medical facilities.

The housing infrastructure for about $75 \%$ of rural women was very poor as revealed by field findings. Some houses consisted of a living room and a bed room where the children's bamboo beds were fixed in the living room that also served as a firewood kitchen and the parent's bamboo beds were fixed in the bed room. The ceilings of these houses were used as storage for harvested maize, beans and groundnuts. Nevertheless, indicators of poverty alleviation as observed and revealed in the field shows that the rural woman's approach to reduce poverty via the diversification of rural activities has played a substantial role in alleviating poverty in her milieu.

\subsection{Indicators of poverty alleviation}

According to IFAD, (2011) the rural woman is the backbone of the rural economy; in addition to caring for her family and her domestic chores, she is involved in producing food crops and rearing livestock and small income generating activities or micro enterprise in a bid to alleviate poverty. The rural non-farm sector needs its due share in development policies as it has the potential to uplift rural areas (Jan, 2012). Diversification of rural activities is essential to promote growth and development in a rural milieu. As ascertained by Alemu, (2012) the fight against poverty in rural areas cannot be won with a great focus on agricultural development; 
employment creation through non-farm activities should also be considered important routes out of poverty. Sharing this same point of view, Kamwi et al., (2017); Khatiwada et al, (2017) further hold that livelihood activities and skills play an important role in augmenting farm income, with most people adopting a combination of livelihood activities. Diversification of rural activities implies a shift from subsistence farming for household consumption to market oriented and non-agricultural activities. The diversification of rural activities so as to diversify income sources in Bui Division is more than simply preventing hunger and suffering, it is a spring-board for economic growth in this study area and reduces immediate poverty and promotes long term human development (Nsahlai, 2015). The rural woman's diversification of rural activities in Bui Division as a strategy towards poverty alleviation has curbed poverty as observed via a number of indicators (Fig. 2).

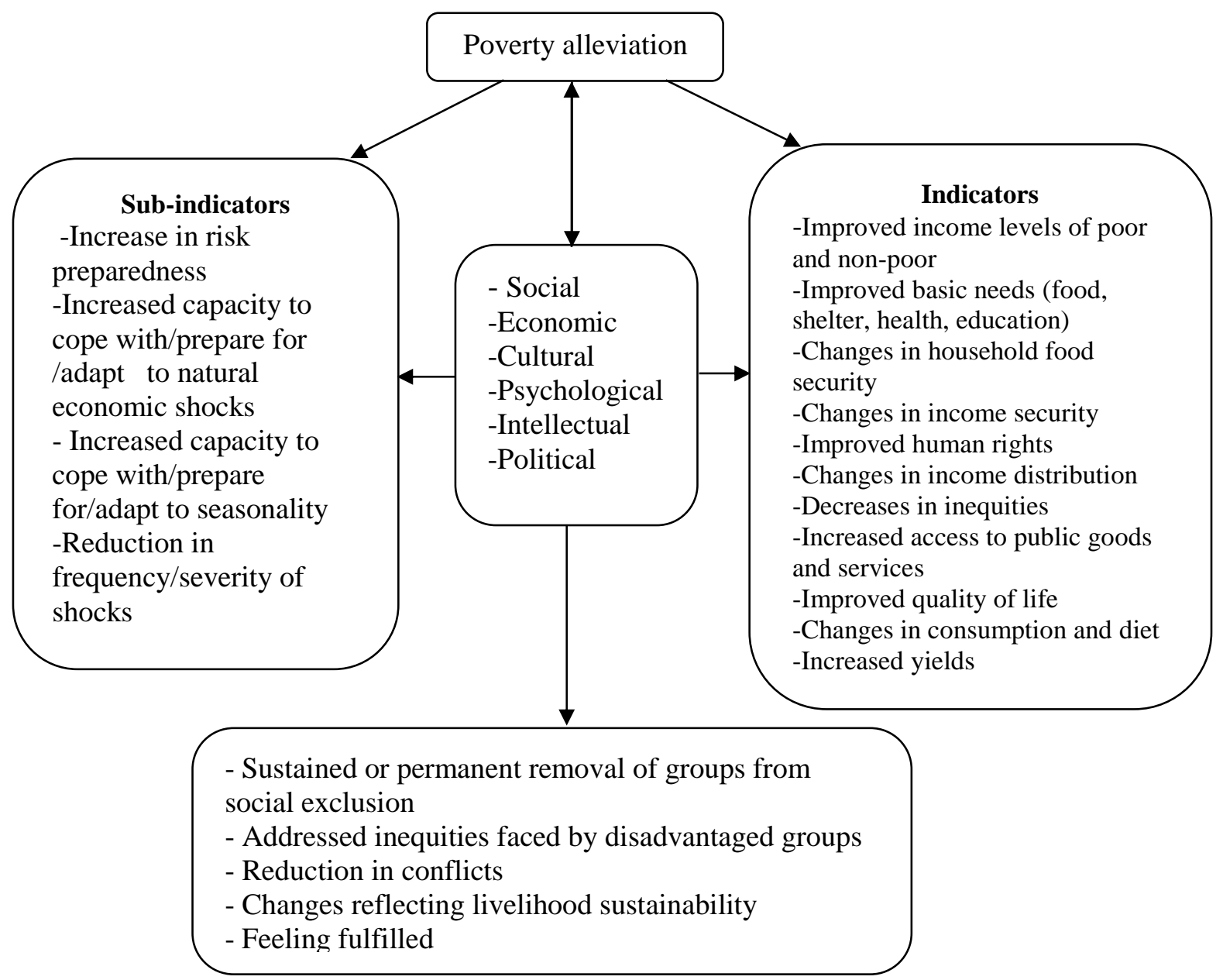

Fig. 2: A model of Poverty reduction in Bui Division

Source: Author's conception and field work (2018)

\subsubsection{Increased access to education, health/nutrition, and upgraded shelter}

The diversification of rural activities is a natural starting point for poor rural producers with low levels of income who may be able to restructure their production and to invest in nonagricultural areas (Hanlon et al., 2010). The rural woman plays an essential role in the fight against hunger and poverty; yet, this role is far from being recognized (Hidalgo Garcia, 2013). 
Increased agricultural output as a result of improved agricultural techniques put into practice by rural women, lead to an increase in revenues. As established by World Bank, (2004), growth of agro-industry employment opportunities represents an opportunity for farmers to diversify income sources through part-time work off-farm, contributing to a reduction of farm related income risks. In Bui Division, revenues gotten from agricultural products are invested in nonfarm activities and in food processing and/or transformation as observed in the field. Non-farm activities involve sewing, trade, knitting, hair dressing, and telephone services. These activities carried out by rural women generate more revenues used in improving their families' living standards (Fig. 3).

- Sharing and transmission of
'new' knowledge and
techniques
- Increased recognition of the
social status of women in
households
- Increase in school
attendance and level of
children's education
- Increase in health
attendance of household
members
- Improved housing
materials, condition and style

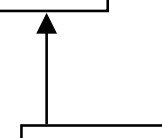

$$
\begin{aligned}
& \text {-Transformation of primary products } \\
& \text { - Food processing and transformation plants } \\
& \text { - Increased practice of innovative agriculture } \\
& \text { - Increased practice of non-farm activities } \\
& \text { - Collective farm work }
\end{aligned}
$$

Fig. 3: A model of the rural woman's process of diversification of rural activities towards poverty alleviation in Bui Division Source: Author's conception and field work (2018)

It is noticed in the field that only about $5 \%$ of rural women carry out diversification without belonging to any form of organization and/or association because they are still searching for an organization that would suit their goals. Ninety five percent $(95 \%)$ of rural women who belong to Thrift and Loan Groups (TLGs) and other forms of organizations have easy access to loans and information on agricultural know-how. Women empowerment through microcredit is a key example of the way poverty can be alleviated by supporting the atmosphere of women empowerment which helps rural poor women to come out from low level balanced traps (Akhter 
and Chery, 2020). The rural woman in Bui Division, thanks to loans gotten from organizations, is able to have access to farm inputs and hire more labour force for her farms in a bid to increase output. Rural women learn improved farming practices and 'new' non-farm activities in training workshops organized by organizations in which she belongs. Rural women carry out collective work in the farms of their group members and this collective work shortens and lightens farm labour. All these actions within groups are aimed at assisting the rural woman in her process of diversifying rural activities. Income gotten by rural women as noted in the field is being used for children's educational facilities, family members' health facilities, improved shelter, clothing, bills and other household equipment (table 1).

Table 1: Rural woman's usage of income gotten from the diversification of rural activities

\begin{tabular}{cccccc}
\hline Sub-division & $\begin{array}{l}\text { Surveyed } \\
\text { population }\end{array}$ & Education & $\begin{array}{l}\text { Health } \\
\text { /Nutrition }\end{array}$ & Shelter & $\begin{array}{l}\text { Household } \\
\text { basic needs / } \\
\text { clothing }\end{array}$ \\
\cline { 3 - 6 } & & 156 & 161 & 121 & 161 \\
Kumbo & 161 & 136 & 134 & 98 & 136 \\
Nkum & 136 & 109 & 110 & 72 & 111 \\
Jakiri & 111 & 90 & 91 & 53 & 91 \\
Noni & 91 & 189 & 200 & 167 & 204 \\
Oku & 204 & 44 & 46 & 39 & 46 \\
mbven & 46 & 724 & 742 & 550 & 749 \\
Total & 749 & 97 & 99 & 73 & 100 \\
$\%$ & 100 & & & & \\
\hline
\end{tabular}

Source: Field work (2018)

Table 1 shows that due to the diversification of rural activities, rural women get more revenues. With these revenues, they are able to fully or partially participate in the health / nutrition of their families and provide for basic household needs like clothing. It has been revealed that $99 \%$ of rural women use their incomes on their households' access to health/nutrition. Rural women also inject their income in buying cloths for household members, buying kitchen and household utensils since they have enough to improve upon their living space by putting most household utensils at their disposal. The table also illustrates that $97 \%$ of rural women carry out the responsibility of educating or contributing to their children's education thereby increasing their access to education (pay their children's school fees, buy their school uniforms, books and other school needs). As such, it has been revealed that $98 \%$ of girls in the study area go to school and have at least completed primary level education.

The remaining $13 \%$ of rural women who do not invest in their children's education are those whose children are already independent, who receive educational assistance from relatives and those who have a Monthly remunerating activity that enables them cater for their children's education. They are able to pay for hospital bills and buy medications for themselves and for others under their care unlike the period before the fall in the commercialization of coffee when they solely depended on their husbands for all financial provisions. Rural women in Bui Division provide food to feed their family members; in addition to this, they equally contribute in buying other food stuffs which they do not cultivate and also buy provisions such as cooking oil, salt, magi, meat, fish and all the like. It is revealed that $57 \%$ of them contribute in paying electricity 
and water bills for their households. About $24 \%$ who pay bills are the divorced, widows and singles. It is obvious that $87 \%$ buy kerosene for kerosene lamps in homes that are not electrified.

\subsubsection{Development and economic growth}

According to Rosegrant and Hazel, (2001) economic growth that focuses on agriculture and that increases the income of poor family farmers and landless labourers is particularly effective in reducing poverty. Diversification increases employment for the rural poor (World Bank, 2004). In this same line, Zergaw, (2004) ascertains that diversifying household income sources is a coping strategy. The diversification of rural activities in Bui Division stimulates economic growth within the area; where, individuals invest and earn more, the local economy is stimulated by increased earnings and these help to promote economic growth. Rural non-farm economy plays a critical role in the income generation of rural households. The sector has grown too large to condone its continuous neglect in rural development policies and poverty reduction programmes (Zezza et al., 2007). Domestic demand makes the largest contribution to economic growth. The massive formalisation of non-agricultural employment is a critical factor that enables increased informal sector earnings and is a stimulus for demand. In Bui Division, the diversification of rural activities stimulates demand since poor people (mostly rural women) spend extra money gotten from diversified rural activities in the local markets. This increases the 'spending power' of families by about $98 \%$. This spending gives a huge socio-economic boost to the study area.

According to DFID, (2005) two and a half (2.5) billion people in developing countries depend on agriculture for their livelihoods. But beyond its direct benefit to rural livelihoods, the agricultural sector has particularly strong links to the rest of the economy, and this is one of the most powerful ways in which it generates overall growth and reduces overall poverty. Agricultural growth is highly effective in reducing poverty. Agriculture contributes to rapid progress in poverty reduction (Cervantes-Godoy and Dewbre, 2010). Investing in the agricultural sector is a key to eradicating poverty, hunger and malnutrition, particularly in rural areas where most of the World's poorest live. In addition to investing in agriculture, reducing poverty also requires investing in rural non-farm economies, (FAO, 2017). According to Feliciano, (2019) crop diversification is one of the most cost-effective ways of reducing uncertainties in farmers' income, especially among poor smallholder farmers. The diversification of rural activities provides a form of insurance. About $89 \%$ of rural women claim that a certain amount of money gotten from their diverse rural activities assures security (reduces insecurity). This is because the rural woman has money to save for emergencies such as sickness, crop failure and releasing money for investment. This situation, in turn, makes smaller levels of savings tolerable and thus, allows more investments in activities such as buying stock for trading, inputs for food processing and transformation, fertilizers and improved seeds for farming. Rural women take the risk of adopting 'new' farming techniques. The risk is taken because they have ready finances gotten from their savings.

As affirmed by Lemi, (2009) diversification of income sources, assets, and occupations is often common practice for individuals or households in different parts of the world but for different reasons. The diversification of rural activities in our study area is the initial capital that enables the poor especially poor rural women to invest. This means that diversification is an efficient way to promote investment and economic growth. The non-poor might think that the 
diversification of rural activities is only for immediate consumption but in fact, it has been revealed that income gotten from the diversification of rural activities is partly used for productive investments (large scale farming by way of buying and/or renting more farmlands and employing farm labourers). It is clear that the diversification of rural activities tends to be more productive and have higher rates of return.

\subsubsection{Socio-cultural dimension}

The diversification of rural activities as noted in the field leads to 'rurbanization' of the study area. That is, the area is losing its aspects of 'rurality' and gaining urban aspects. Livelihood diversification to non-farm activities (business and enterprises) are more lucrative strategies and relevant for poverty reduction (Khatiwada et al, (2017). The study area, thanks to the diversification of agricultural to non-agricultural activities, many informal activities with their existing structures or infrastructures such as tailoring workshops, hairdressing saloons, barbing studios, call-boxes, restaurants, bars and shops which are mostly activities of urban areas are gaining more grounds in rural milieus within our study area; Life is not solely dependent on agriculture as it is the case with a stereotype rural milieu.

The housing styles in the study area are greatly improved upon as compared to the period before the fall in coffee prices in the 1980s. Thanks to income gotten from diversified rural activities, a majority of the houses are roofed with iron sheets instead of grass. Most of the houses are plastered, have cemented floors, electrified and painted. In Jakiri, Nkum, Oku and in Kumbo sub-divisions for example, about $97 \%$ of homes are channeled with pipe born water from Cam Water and/or Community water projects (thanks to community work carried out by respondents by way of digging channels from water catchments areas to their quarters and homes. As observed in the field, with the diversification of rural activities most especially by the rural woman, $99 \%$ of houses are roofed with zinc (fig 4B and 6) thanks to the diversification of rural activities; a few grass roofed (fig 4A and 5,) houses are used as kitchens and warehouses for farm products. All these changes result in spatial differentiation.

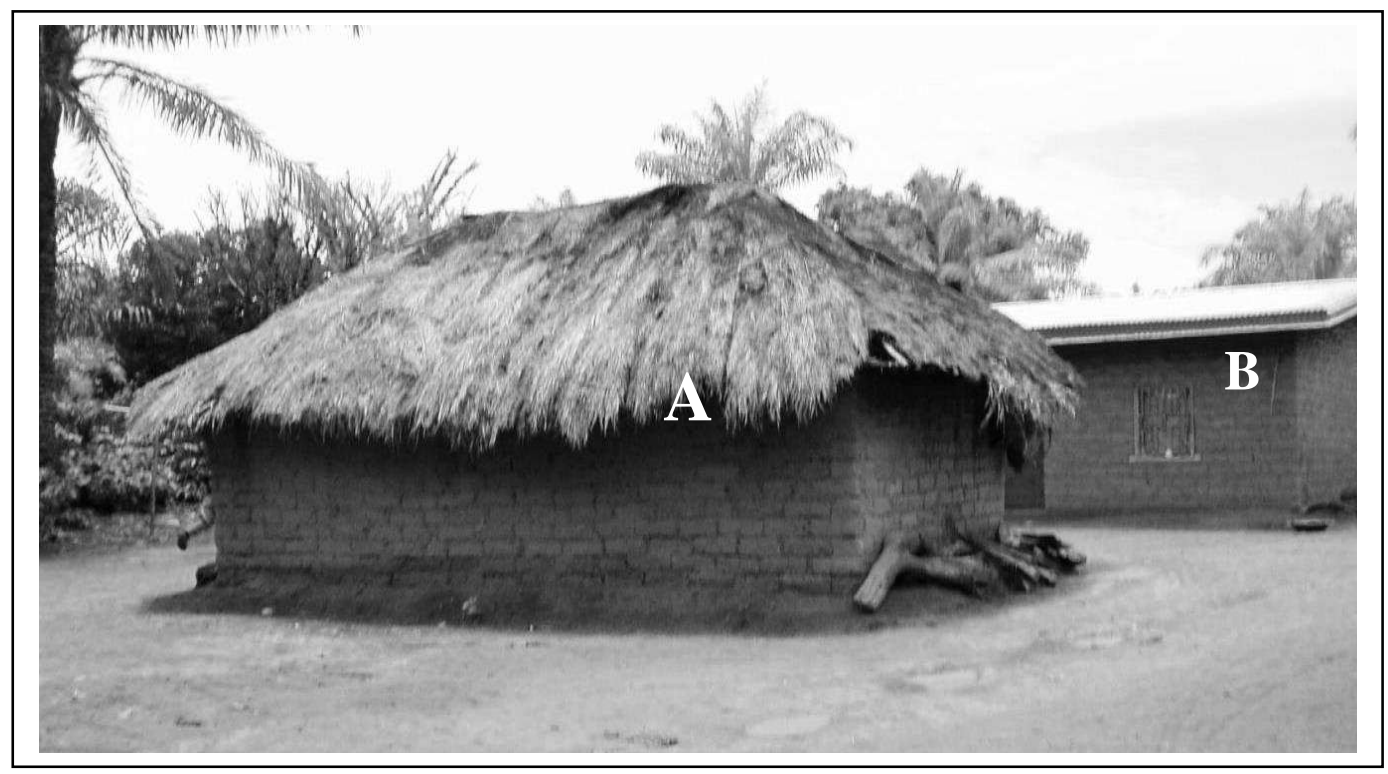

Fig. 4: Housing infrastructure before (A) the diversification of rural activities and after (B) 


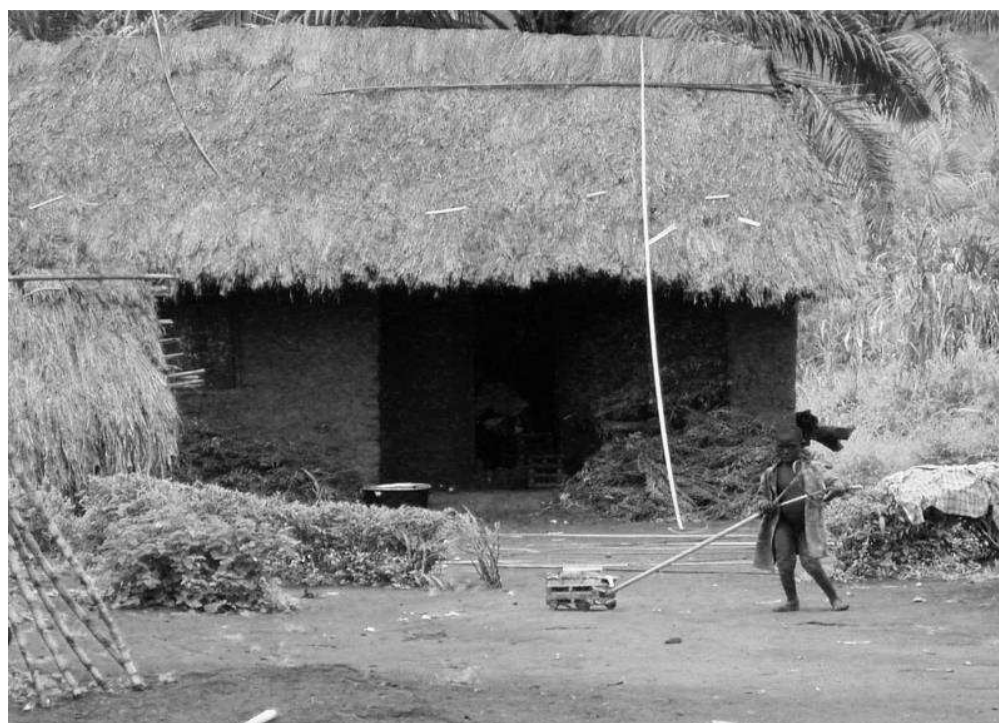

Fig. 5: Grass roofed house (formal residence) now used as firewood kitchen and farm warehouse

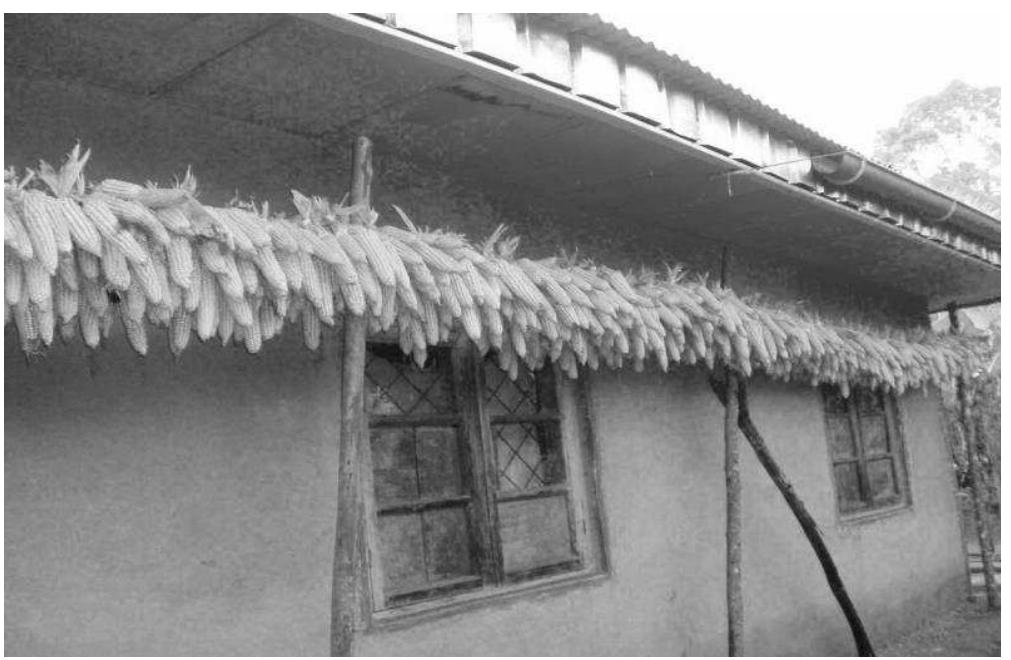

Fig. 6: Newly constructed Zinc house with plastered walls and cemented floor serving as new residence

\subsubsection{Social protection and security}

According to Oluwatayo, (2009) agriculture alone does not provide sufficient livelihood opportunities; hence, diversification into non-farm activities is seen as a form of self-insurance because diversification offers people options for coping with crises. Income diversification is considered one of the important households' strategies for securing rural livelihoods (Loisin and Bignebat, 2017). The diversification of rural activities in Bui Division has its core purpose of raising the income of the 'poor' and 'poorest'. According to UNICEF, (2000) when poverty strikes a family, the youngest members become its most innocent and vulnerable victims. Societies have always acknowledged their responsibility to those who cannot be productive such as the young, old and disabled. Thus, in Bui Division, those who are capable (the physically strong), increasingly share the responsibility of providing support required by the young, old and disabled (table 2). 
Table 2: The category of people who received assistance from rural women

\begin{tabular}{cccccc}
\hline Sub-division & $\begin{array}{l}\mathbf{N}^{\circ} \text { of } \\
\text { respondents }\end{array}$ & \multicolumn{4}{c}{$\begin{array}{c}\text { Category of persons to which assistance was } \\
\text { provided by respondents }\end{array}$} \\
\cline { 3 - 6 } & & Young & Old & Disabled & Non \\
\hline Kumbo & 161 & 137 & 97 & 2 & 2 \\
Nkum & 136 & 129 & 136 & - & - \\
Jakiri & 111 & 111 & 97 & 1 & - \\
Noni & 91 & 89 & 68 & - & 1 \\
Oku & 204 & 196 & 198 & 3 & 4 \\
mbven & 46 & 43 & 41 & 2 & - \\
Total & 749 & 705 & 637 & 8 & 7 \\
$\%$ & 100 & 94 & 85 & 1 & 1 \\
\hline
\end{tabular}

Source: Field work (2018)

Table 2 reveals that $94 \%$ of rural women in Bui Division take care of the young who are their biological children, children of relatives and/or adopted children. Rural women undertake the responsibility of caring for the young children's feeding, education, medical assistance and clothing. These undertakings reduce the effect of poverty on young children in the study area. The remaining 6\% who do not provide assistance to the young are those who have just enough for themselves or have no young ones to care for. It is obvious that $85 \%$ of rural women provide assistance to the old who are helpless to themselves. Assistances given to old persons as revealed by field findings are medical, shelter, feeding and clothing. A negligible $2 \%$ of rural women in the field offer assistance to the disabled and some do not provide assistance to other persons for no tangible reason and/or because it has never occurred to them to do so.

These various forms of assistances provided by rural women to those who are not physically strong and unable to diversify rural activities such as the young, old and disable enable them to gain social protection and security. That is, despite their vulnerable state as observed in the field, they feel socially protected and secured from any risk. This form of social protection/security is a good indicator of poverty reduction in the study area. Another form of social protection and security is that some respondents are employed and have a monthly wage that range from 10,000FRS CFA to 40,000FRS CFA except for about 5\% who are civil servants. These incomes are too small to support their families and it is noted that the diversification of rural activities is an immediate approach of bringing their earnings to a closer satisfactory level (a level at which a rural woman can easily assure her basic needs such as appropriate shelter, health, education, clothing of family members and consumption of different food varieties gotten from the market). The diversification of rural activities also creates safety nets where help is given to those who cannot carry out agricultural and non-agricultural activities because they are ill, injured or whose crops have failed due to bad weather or climate variability.

\subsubsection{Rights, equity and fairness}

Over the past decades, the international community's concern with poverty has been rising with an increased attention accorded to the realization of human rights. Lifting the world's poor out of poverty, however, will require the translation of good intentions and promises into concrete action. This action must do more than merely boost incomes (UNICEF, 2000). No poor 
country has ever successfully reduced poverty through agriculture alone, but almost none has achieved it without first increasing agricultural productivity (Haggblade et al, 2002). Dutta, (2016) continued in this same line ascertaining that diversifying activities make greater contribution to generate cash incomes for poorer households and it is a key strategy by which people try to make ends meet and improve their wellbeing. Agricultural diversification is seen as a 'gate-way' because it gives openings to other outlets that are income generating for the wellbeing of rural masses. In other words, it is the 'starting point' for the uplift of living standards. In this same line, FAO, (2017) upholds that investing in agricultural sectors is key to eradicating poverty, hunger and malnutrition particularly in rural areas where most of the world's poorest live; in addition to investing in agriculture, reducing poverty requires investing in rural non-farm economies. In Bui Division, rural women carrying out diversification and their family members (deserving or undeserving in line with the Universal Declaration of Human Rights) enjoy an adequate living standard that ties with the social norms of the milieu as attested by field findings. It is revealed that $79 \%$ of households have increased 'rights', equity and fairness within their milieu; this is thanks to increases in households' income resulting from the diversification of rural activities.

\subsubsection{Human capital and breaking of inter-generational poverty cycle}

Children are the hardest hit by poverty; it causes lifelong damage to their minds and bodies. They are therefore, likely to pass poverty on to their children, perpetuating the poverty cycle. Poverty reduction must begin with children (UNICEF, 2000). The diversification of rural activities in Bui Division directly improves the well-being of children, old persons and disables. Being able to have income implies that there is money to buy food stuffs which are not cultivated by rural women such as palm and/or groundnut oil, salt, meat, fish, rice and others. As such, health is improved upon because there is better nutrition, increased ability for family members to go to hospitals when they face challenges with their health. Children are better fed and can go to school and have a better performance. That is, money that is gotten from the diversification of rural activities has increased the school attendance of girls. In so doing, poverty caused by individual's choices is curbed.

Although improved health and education can be seen as valuable gains in themselves, they also improve the productive capacity of poor households. The main asset that poor people have is themselves and their labour-force. So, the diversification of rural activities has boosted their capacities thereby increasing human capital and as such, more farmlands are cultivated because people have become healthier, stronger and have enough human energy for labour investment on their farm plots. Diversifying rural activities breaks the intergenerational poverty link of about $47 \%$ of households. This is because the diversification of rural activities is a key way to redress inequalities in rural areas by helping to ensure that children, old, disabled and poor families are well fed, are healthier and are more educated than their parents.

\section{Conclusion}

The purpose of this paper was to show that poverty alleviation in Bui Division is a response to the rural woman's diversification of rural activities. The diversification of rural activities by the rural woman is vital in poverty alleviation strategies. However, the rural woman's role in poverty alleviation via the diversification of rural activities tends to be 
unnoticed and is not recorded in statistics and mentioned in reports. This implies that her contributions are poorly understood and underestimated. Poverty alleviation approach should involve not only government; the population especially rural women who are the most affected by poverty should be imperatively involved. The diversification of rural activities in Bui Division stimulates economic growth; where, individuals invest and earn more, the local economy is stimulated by increased earnings and these help to promote economic growth. With the increases in income, there is a rise in the level of productivity; rural women undertake the responsibility of caring for the young children's feeding, education, medical assistance and clothing. This implies a reduction on the effects of poverty on young children, old persons and disables. As a result of this, there is an increase in the productive capacity of poor households. Considering and recognising the rural woman's activities in National Statistics and Poverty Reduction Strategy Papers is vital in alleviating poverty especially in rural milieus where people are highly affected.

\section{References}

Ade-Lawal, N., 1986. Issues, Concepts and theory of poverty in Nigeria. SAGE Journals vol (41) issue 4. https://doi/10.1177/097492848604200305

Alemu, Z. G., 2012. Livelihood Strategies in Rural South Africa: Implications for poverty Reduction. Selected paper prepared for presentation at the International Association of Agriculture Economists (IAAE) Triennial Conference, Foz do Igaucu, Brazil. P 24

Awotide, D.O., Agbola, P., Kehinde, A., 2010. Poverty and rural livelihood diversification among farming households in southwest Nigeria. Journal of Food Agriculture and Environment. Vol.8 (1): 367-371. www.world-fodd.net.

Bradshaw, T.K., 2005. Theories of poverty and anti-poverty programs in Community development. P 22

Zezza, A., Carletto, G., Covarrubias, K., Davis, B., 2007. Rural income generating activities in developing countries: re-assessing the evidence. Journal of Agricultural and Development Economics. Agricultural Development Economics Division (ESA) FAO Vol 4. No.1, pp. 146-193. P 48

Cervantes-Godoy, D., Dewbre, J., 2010. "Economic Importance of Agriculture for Poverty Reduction", OECD publishing. P 27

Chinake, H., 1997. Strategies for poverty alleviation in Zimbabwe. Journal of Social Development in Africa, 12, 1, 39-51

Cromwell, E., Luttrell, C., Shepherd, A., Wiggins, S., 2005. Poverty reduction strategies and the rural productive sectors: Insights from Malawi, Nicaragua and Vietnam. ODI working paper 258. Oversees Development institute. 111 Westminster Bridge Road London SE1 7DJ.UK. p 32

DFID, 2005. Growth and poverty reduction: the role of agriculture. A DFID policy paper. P 62

Dutta Sikha (2016). Problems and prospects of livelihood diversification among the missing and Sonowal Kachari rural tribes in Dibfugarh District in Assam. www.nird.org.in . P 24

FAO, 2017. Ending poverty and hunger by investing in agriculture and rural areas. FAO of the United Nations; Rome. http://www.fao.org/3/a-i7556e.pdf.

Feliciano, D., 2019. A review on the contribution of crop diversification to Sustainable Development / Volume 27, issue 4

Garcia Maria D.M. H., 2013. The Role of Women in Food Security. Book chapter in, FAO Statistical Year book. Pp. 82-96. P 15 
Handley, G., Higgins, K., Sharma, B., Bird, K., Cammack, D., 2009. Poverty and poverty reduction in sub-Saharan Africa. An overview of the issues. Overseas Development Institute, working paper 209. P 82

Ghosh, J., 1998. Assessing poverty alleviation strategies for their impact on poor women: Study with special reference to India, United Nations Research Institute for Social development (UNRISD). P 56

Haggblade, S., Hazell P., Reardon T., 2002. 'Strategies for Stimulating Poverty - Alleviation Growth in the Rural Non-Farm Economy in Developing Countries'. Environment and production Technology Paper 92, IF PRI, Washington DC.

Jan, I.T., Khattak, M.K., Khan, M.A., Hayat, S., Rahim, T., 2012. Factors affecting rural livelihood choices in North West Pakistan. Sarhad Journal of Agriculture. Vol 28, No 4. P 9

Jan, H., 2010. Becoming poor in Ghana. ISS Students' compendium 2013, International Development Studies, University of Oslo. Pp 1-13

Kamwi, J.M., Chirwa, P.W.C., Graz, F.P., Manda, S.O.M., Mosimane, A.W., Kätsch, C., 2018. Livelihood activities and skills in rural areas of the Zambezi Region, Namibia: Implications for policy and poverty reduction. African Journal of Food, Agriculture, Nutrition and Development. Vol 18. No 1.

Kehinde, O.J., 2010. Poverty alleviation strategies and the challenge of governance in Nigeria: The way forward from legion of failed policies. Journal of Management and Organisational Behaviour 1(3) 81-93, ISSN 0794-0331

Khatiwada, S.P., Deng, L.,Paudel, B., Khatiwada, J.R., Zhang, J., Su, Y., 2017. Household livelihood strategies and implication for poverty reduction in rural areas of Central Nepal. Sustainability, MDPI, Basel, Switzerland. P 20

Kimani, E.N., Kombo, D.K., 2010. Gender and Poverty Reduction: A Kenyan Context. Eductional Research and Reviews. Vol.5(01). Pp 024-030

Lavallee, et al., 2010. Poverty Alleviation Policy Targeting: A Review of experiences in developing countries. IRD. P 29

Lemi, A., 2009. Derterminants of income diversification in rural Ethopia: Evidence from panel data. Ethopian Journal of Economics, Ethopian Economics Association, vol.18(1), pp 116-116

Lempert, D., 2020. A poverty reduction accountability indicator for international governments organisations and NGOs

Loisin, S.A., Bignebat, C., 2017. Patterns and determinants of household income diversification in Rural Senegal and Kenya. Journal of Poverty Alleviation and International Development. 8(1)

Nsahlai, L.K., 2015. The rural woman as an actor in the diversification of rural activities towards poverty reduction in Bui Division, North West Region - Cameroon. PhD thesis, the University of Yaounde 1 - Cameroon. P 313

Oluwatayo, I.B., 2009. Poverty and income diversification among households in rural Nigeria: a Gender Analysis Livelihood Patterns. Instituto de Estudos Sociais e Económicos (IESE) Conference on "Dynamics of poverty and patterns of Economic accumulation in Mozambique. Maputo, Mozambique

Rosegrant and Hazel, 2001. Transforming the rural Asian economy: the unfinished Revolution. A 2020 Vision for Food, Agriculture, and the Environment. 2020 Brief 69

Shepherd, A., Hulme, D., 2003. “Conceptualizing chronic poverty”, in World Development. The 
multidisciplinary International Journal Devoted to the Study and Promotion of the World Development 31 (3), pp. 403-423. ISS students' compendium, International Development Studies, 2013, University of Oslo, Norway.

Singleton, D., 2003. Poverty Alleviation: the role of the engineer. P 29

Tah N.R., 2016. The determinants of poverty in Cameroon. Journal of Economics and Sustainable Development, No.10. p 110-118.

UNICEF, 2000. Poverty reduction begins with children. New York .

World Bank (2017). Growing the Rural Nonfarm Economy to Alleviate Poverty. An evaluation of the contribution of the World Bank Group. An independent Evaluation. Washington DC. P 289

World Bank, 2016. Poverty and Shared Prosperity 2016: Taking on inequality, Washington DC: World Bank

World Bank, 2004. Agricultural diversification for the poor. Guidelines for Practitioners. Agriculture and rural Development Discussion Paper 1.

World Bank, 2004. The poverty reduction strategy initiative. An Independent Evaluation of the World's Bank's Support through 2003. World Bank, Washington DC. P 105

World Bank, 1990. Women in development. A Progress Report on a World Bank Initiative. World Bank, Washington. P 32

Zergaw Sara Worku (2007). Livelihood strategies of rural women with emphasis on income diversification and demographic adjustment: the case of Wolonkomi, Oromia region. Working papers on population and landuse change in central Ethopia. Addis Ababa University, nr.9. p 36 